and technology, for which a national committee has been established under the chairmanship of Dr Yehuda Kela (chief scientist of the Ministry of Communications), biotechnology (on which a preliminary report has just been completed by a team headed by Professor Ephraim Katchalsky Katzir) and technology specifically relevant to the Israeli environment (such as solar energy, solar ponds and desalination). Relatively little formal world planning of this third sector has been done so far, but all three sectors are well advanced commercially. At this stage, Ne'eman's ministry seems more concerned to give government approval (and possibly material support) to promising developments than to initiate them.

This situation is doubtless temporary. One of Dr Ne'eman's first actions as Minister of Science was to set up (under his own chairmanship) an Israeli space agency, which initially coordinated research already under way at Israeli universities, but which afterwards began to initiate projects. One such is the recent agreement with the United States for a large laser to be sited near Jerusalem for use in a bilateral programme on geodynamics (in conjunction with a satellite from the National Aeronautics and Space Administration) and which, when the satellite is not above the horizon, can also be used for meteorological and atmospheric pollution studies.

Dr Ne'eman seems a little dismayed that the Israeli press has, so far, almost entirely ignored the country's space effort. Even the political implications of Israel's application to Intelsat for a position for a geosynchronous communications satellite have made only a little impact although more than 30 overseas objections have been filed with the International Telecommunications Union, mainly from the Arab bloc.

The only "scientific" problem which the media seem keen to raise with him is the question of a possible Israeli nuclear bomb. Here, however, Dr Ne'eman's stance is unchanging - between the "doves", who would like Israel to sign the non-proliferation treaty, and the ultra-hawks, who would like to announce a definite commitment to nuclear weaponry, Ne'eman believes Israel's best hope of keeping out of a nuclear conflict lies in keeping the world guessing about its nuclear capability.

On the survival of his ministry, however, Ne'eman has recently received some coverage. Some three weeks ago the daily Ha'aretz acquired a leaked copy of a new report on science and technology in Israel, the first such document for fifteen years. Its predecessor, the Katchalsky report, led, among other things, to the establishment of chief scientists in all relevant ministries and also urged the establishment of a Ministry of Science, a suggestion rejected by the then prime minister Ashkol as politically inappropriate at the time.

The new report, drawn up by a commis- sion headed by Professor Shimon Yiftah of the Technion at Haifa, a former head of the atomic energy establishment at Soreq, also strongly supports the concept of a Science Ministry, leading to the $\mathrm{Ha}^{\prime} \mathrm{aretz}$ headline: "Science Ministry will not be abolished".

\section{Israeli innovation}

\section{Biggest science park so far}

\section{Rehovot}

ISRAEL, which already has several flourishing science-based industrial parks, is to have its first fully-fledged science region. Although the project was formally approved by the government only last month, a number of companies are already operating.

The area, to be called, with just a touch of hyperbole, Region 2000 , is expected to transform the Western Galilee, a sparsely populated area hitherto mainly devoted to agriculture and tourism, into a thriving centre of high-technology industry.

The scheme is the brainchild of Professor Ephraim Katzir of the Weizmann Institute, one of Israel's leading scientists and its fourth president, who has long argued that with proper planning, a large number of entrepreneurs, scientists and technicians can be attracted to the "unspoilt beauty of the Galilee". But not everyone is enthusiastic. Critics have pointed out that the existing science parks are all near well-established universities and research centres, which provide them with consultants, computers, libraries and other resources. None of these are readily available, they declare, in the Western Galilee.

This has not deterred the Ministry of Industry and Commerce, which is closely linked with the Region 2000 scheme. A ministry spokesman points out that Israel is a very small country and that the Western Galilee is only about 50 minutes by automobile from the Haifa Technion. Moreover, he adds, Sophia Antipolis, the French science city, is much further away from established universities and research centres, but has nevertheless succeeded in attracting some 60 enterprises. Situated as it is on the Riviera near Antibes, it can offer lovely surroundings and a quality of life that is not available in the older industrial regions of France.

The companies already operating in Region 2000 are chiefly offshoots of established science-based industries with headquarters in the crowded coastal plain. They include Elscint (diagnostic imaging), Elbit (computer-based systems) and Dand Iscar (jet engine compressor and turbine blades, as well as other hard-metal products).

Smaller science-based enterprises are linked to rural settlements in the area. Among them are Me'ad Computers (a software house specializing in administrative and managerial systems) at Moshav Ya'ad and Biological Industries (where advanced commission can only recommend, not compel government action. The $\mathrm{Ha}^{\prime} \mathrm{aretz}$ headline, however encouraging to Ne'eman and his supporters, remains a piece of speculation.

Vera Rich
Like its predecessor, however, the Yiftah

tissue culture techniques are used to propagate ornamental plants free of specific pathogens) at Kibbutz Beit Ha'emek.

The existing enterprises have now been joined by two plants connected with Rafael, the Defence Ministry's weapons development authority, but only one of these will be dealing with the development and manufacture of arms - air-to-air missiles. The other, run independently under the name of Galram, will work on civilian products based on spin-offs from Rafael's military research and development.

Since existing and new enterprises in Region 2000 will need skilled manpower, high-technology vocational schools are being established to train thousands of Arab, Druze and Jewish youth; the Jewish students, who will be accommodated in a school run by the ORT organization, will include a large proportion of young people from abroad.

Economic incentives are offered to all science-based industries in Israel but, since Region 2000 is in Israel's hinterland, incentives to companies setting up there will be much more generous than those given to companies that turn to science parks in Haifa, Tel Aviv or Rehovot.

They will include cash grants and lowinterest loans covering up to 75 per cent of the investment in fixed assets, 50 per cent government cost-sharing for approved research and development projects, lowinterest loans to finance working capital for production, low rentals for industrial premises, a seven-year tax holiday and only 30 per cent corporate taxes. There are also special provisions to protect equity against the effects of inflation and devaluation and accelerated depreciation arrangements so that equipment can be depreciated in four years and buildings in five.

To minimize initial investment costs even further, new enterprises will be able to obtain basic administrative services from a shared services centre. These include accounting and financial services, secretarial services, production of promotional material, transport arrangements and computer and telex facilities.

Israel already exports goods to a value of more than US $\$ 1,000$ million a year in sophisticated products based primarily on local research and development and, by the end of the 1980s, according to forecasts from the Ministry of Industry and Commerce, that figure should rise to $\$ 5,000$ million. Whether or not it does will depend, in no small measure, on the success of Region 2000.

Nechemia Meyers 